\title{
APLIKASI SISTEM PA KAR PADA DIAGNOSA PENYAKIT HIPERTENSI DAN DIABETES BERBASIS WEB MENGGGUNAKAN METODE FORWARD CHAINING \\ ${ }^{1}$ Pria Sukamto, ${ }^{2}$ Suherlan, ${ }^{3}$ Haryanto \\ ${ }^{1,2}$ Sekolah Tinggi Teknologi Muhammadiyah Cileungsi, Indonesia. \\ ${ }^{3}$ STMIK Bani Saleh-Bekasi, Indonesia \\ Email: ${ }^{1}$ priasukamto@gmail.com, ${ }^{2}$ suherlan611@gmail.com, ${ }^{3}$ faeyza33@gmail.com
}

\begin{tabular}{l}
\hline Article Info \\
\hline Article history: \\
Received, 16/10/2020 \\
Revised, 3/11/2020 \\
Accepted, 18/11/2020 \\
\hline Kata Kunci: \\
Sistem Pakar \\
Forward Chaining \\
Makanan Intant \\
Hipertensi \\
Diabetes \\
\hline \hline
\end{tabular}

Keywords:

Expert System

Forward Chaining

Infant Food

Hypertension

Diabetes

\begin{abstract}
ABSTRAK
Dengan pesatnya dunia teknologi ditandai perkembangan kecerdasan buatan pada teknologi komputer maka berkembang pula dari gaya hidup masa ini sehingga dengan berkembangnya gaya hidup manusia sehingga merubah pula pola makan yang tidak teratur atau kadang-kadang jenis makanan instan yang bisa memicu dan berpengaruh pada sistem kesehatan manusia diantaranya penyakit diabetes dan hipertensi. Salah satu timbul penyakit disebabkan karena keengganan manusia dalam mengontrol kondisi kesehatan misalnya memeriksa pada dokter tentang penyakit tertentu. Dengan latar belakang permasalahan diatas perlu adanya suatu sistem diagnosa penyakit secara lebih fleksibel dengan menggunakan sistem pakar. Dalam implementasinya dirancang sistem pakar diagnosa penyakit hipertensi dan diabetes dengan menggunakan metode forward chaining karena penyakit ini dirasa perlu dikontrol dengan menggunakan sistem pakar. Dengan adanya sistem pakar dalam diagnosis penyakit hipertensi dan diabetes diharapkan mendeteksi penyakit secara dini dengan cepat sebelum dilanjutkan pengobatan secara maksimal ke dokter
\end{abstract}

\section{ABSTRACT}

With the rapid development of the world of technology, marked by the development of artificial intelligence in computer technology, the development of today's lifestyle has resulted in the development of human lifestyles so that they also change irregular eating patterns or sometimes types of instant food that can trigger and affect the human health system including diabetes and hypertension. One of the causes of disease is the reluctance of humans to control health conditions, for example checking with doctors about certain diseases. With the background of the above problems, it is necessary to have a more flexible disease diagnosis system using an expert system. In its implementation, an expert system for diagnosing hypertension and diabetes is designed using the forward chaining method because this disease needs to be controlled using an expert system. With the existence of an expert system in diagnosing hypertension and diabetes, it is hoped that early detection of the disease quickly before proceeding with maximum treatment to the doctor

This is an open access article under the CC BY-SAlicense.

\section{Penulis Korespondensi:}

Wilarso

Program Studi Mesin,

Sekolah Tinggi Teknologi Muhammadiyah Cileungsi,

Email: wilarso@sttmcileungsi.ac.id

\section{PENDAHULUAN}

Seiring dengan meningkatnya perkembangan teknologi pada masa sekarang ini sejalan dengan peningkatan kecerdasan pada pola pikir manusia yang semakin berkembang dan maju sehingga dampak dapat dirasakan dengan penemuan pada teknologi yang membantu manusia dalam 
memecahkan persoalan pada kehidupan sosial, ekonomi dan bisnis, hal tersebut dapat dilihat dari perkembangan ilmu komputer yang semakin hari semakin maju. Sejalan dengan berkembangnya ilmu komputer maka penggunaan komputer menimbulkan perubahan pada pola dan gaya hidup manusia terutama dalam pola konsumsi sehingga membawa dampak yang positif dalam peningkatan produktivitas dan dampak negatif menyebabkan penyakit dari gaya hidup yang kurang teratur ini.

Salah bentuk kecerdasan pada teknologi komputer yang bisa membantu dan dimanfaatkan oleh manusia dengan cara melakukan pemrograman sehingga komputer menjadi cerdas. Bentuk kecerdasan komputer yang bisa melakukan atau berperilaku seperti manusia atau layaknya seorang ahli dinamakan kecerdasan buatan terkenal dengan nama sistem pakar atau Artificial Intelligence. Dimana sistem pakar yaitu merupakan program komputer yang menjadikan komputer menjadi cerdas sehingga mempunyai perilaku dalam mirip dengan manusia sehingga dapat digunakan dalam membantu manusia dalam pengambilan keputusan dan pemecahan masalah sesuai bidangnya secara spesifik[1].

Salah bentuk kecerdasan buatan atau sistem pakar yang bisa dimanfaatkan dalam membantu penyelesaian masalah adalah pada bidang medis. Salah satu bentuk kecerdasan buatan yang bisa dimanfaatkan dalam bidang medis adalah berupa bentuk penyelesaian dan analisis atu diagnosa pada penyakit dan memberikan saran dan masukan sebagai media untuk konsultasi pada bidang pengobatan atau penyakit tertentu. Sehingga kecerdasan ini bisa memudahkan manusia dalam melakukan kontrol kesehatan secara mudah dan fleksibel sehingga bisa mendeteksi gejala penyakit secara lebih dini.

Penyakit yang disebabkan karena kadar insulin meningkat pada tubuh manusia yang disebabkan karena metabolisme tubuh yang tidak baik adalah penyakit diabetes. Dimana penyakit ini dikarenakan tubuh tidak bisa lagi mengolah atau mengkonversi gula secara optimal yang ada didalam tubuh atau dalam darah. Hal ini yang menyebabkan hiperglikemia, atau suatu keadaan gula darah tingginya sudah membahayakan[2]. Secara umum penyakit diabetes terbagi kepada dua tipe adalah diabetes tipe 1 dan diabetes tipe 2 . Sedangkan penyakit hipertensi merupakan penyakit yang terjadi karena terjadi jalur darah yang mengalir dari jantung keseluruh tubuh yang terjadi secara kronis. Kejadian tersebut disebabkan organ fital jantung terus bekerja dalam memenuhi oksigen dan nutrisi untuk seluruh tubuh, dengan kerja jantung yang bekerja extra keras tersebut akan menyebabkan terganggunya fungsi organ yang sangat fital dalam tubuh[3]. Kedua penyakit ini merupakan penyakit yang berbahaya bila tidak dikontrol oleh penderitanya. Menurut data dari Kementrian Kesehatan Republik Indonesia (Kemenkes RI) melalui sebuah riset tentang kesehatan yang terdapat pada (Riskesdas 2013) banyaknya jumlah penduduk Indonesia yang terdiagnosa diabetes sebanyak 12.191.564 jiwa. Sedangkan untuk penyakit tekanan darah tinggi atau hipertensi berjumlah kurang lebih sekitar 65 juta jiwa, bila saat tahun 2013 perkiraan sebanyak kurang lebih 252 juta jiwa maka yang terkena penyakit tekanan darah tinggi berkisar $25 \%$ penduduk Indonesia terkena penyakit hipertensi. Memang kedua penyakit ini menjadi tantangan besar di Indonesia. Dimana jenis penyakit karena tekanan darah tinggi ini sering ditemukan dalam pengecekan pelayanan kesehatan. Salah satu contoh kasus yang terdapat di klinik PKO Muhammadiyah Cileungsi pada tahun 2018 ini ada 15 (lima belas) pasien yang menderita hipertensi dan diabetes. Saat ini ke 15 (lima belas) pasien tersebut rutin melakukan pengobatan dan juga melakukan kontrol terhadap penyakit yang diderita.

Banyak faktor yang menjadi permasalahan tentang kelebihan kadar gula dalam darah dan tekanan pada darah ini, diantaranya adalah rendahnya kesadaran pada masyarakat terkait pemeriksaan penyakit hipertensi dan diabetes, kurangnya tenaga medis spesialis diabetes dan hipertensi, kurangnya media pengecekan untuk masyarakat dan rendahnya masyarakat yang mengadakan pengecekan insulin pada tubuh atau juga bisa disebabkan kurangnya kualitas pengobatan hipertensi dan diabetes.

Tujuan dari penelitian untuk membangun sistem pakar tentang diagnosa untuk mendeteksi kelebihan kadar gula dalam darah atau diabetes dan tekanan darah yang tinggi atau hipertensi yang dimaksudkan untuk dapat digunakan oleh masyarakat sebagai tempat untuk melakukan konsultasi sebagai langkah awal mendiagnosa suatu gejala penyakit yang dirasakan. Sistem ini juga dimaksudkan untuk menambah wawasan masyarakat tentang penyakit diabetes dan hipertensi, dari gejala-gejalanya, penanganannya sampai pada pencegahannya. 
JSAI : Journal Scientific and Applied Informatics

Vol. 3, No. 3, November 2020, hal. 86-94

E-ISSN: 2614-3054; P-ISSN: 2614-3062, accredited by Kemenristekdikti, Sinta 5

DOI: 10.36085

\section{METODE PENELITIAN}

A. Arti Sistem Pakar

Sistem aplikasi komputer atau perangkat lunak yang berisi paket program sebagai penyedia nasehat layaknya seorang ahli dalam membantu memecahkan masalah dibidang ilmu pengetahuan tertentu atau lebih spesifik, rekayasa matematika, kedokteran, pendidikan dan lain-lain [4].

Menurut [5],[6],[7],[8] menyatakan bahwa sistem pakar adalah sistem aplikasi komputer dimana dalam melakukan fungsinya menggunakan pengetahuan, fakta dan teknikteknik analisis secara matematis dalam melakukan pemecahan masalah dan biasanya perilaku manusia ini hanya bisa dilakukan oleh seorang pakar pada bidang tertentu.

\section{B. Arsitektur Sistem Pakar}

Sebuah sistem pakar[9], terdiri dari beberapa komponen diantaranya memiliki user interface (antar muka), expert system database (basis data sistem pakar), knowledge acquisition facility (fasilitas akuisisi pengetahuan) dan inference mechanism (mekanisme inferensi). Dan ada jenis sistem pakar yang menyediakan komponen tentang explanation facility (fasilitas penjelasan). Contoh dari arsitektur seperti pada gambar dibawah ini:

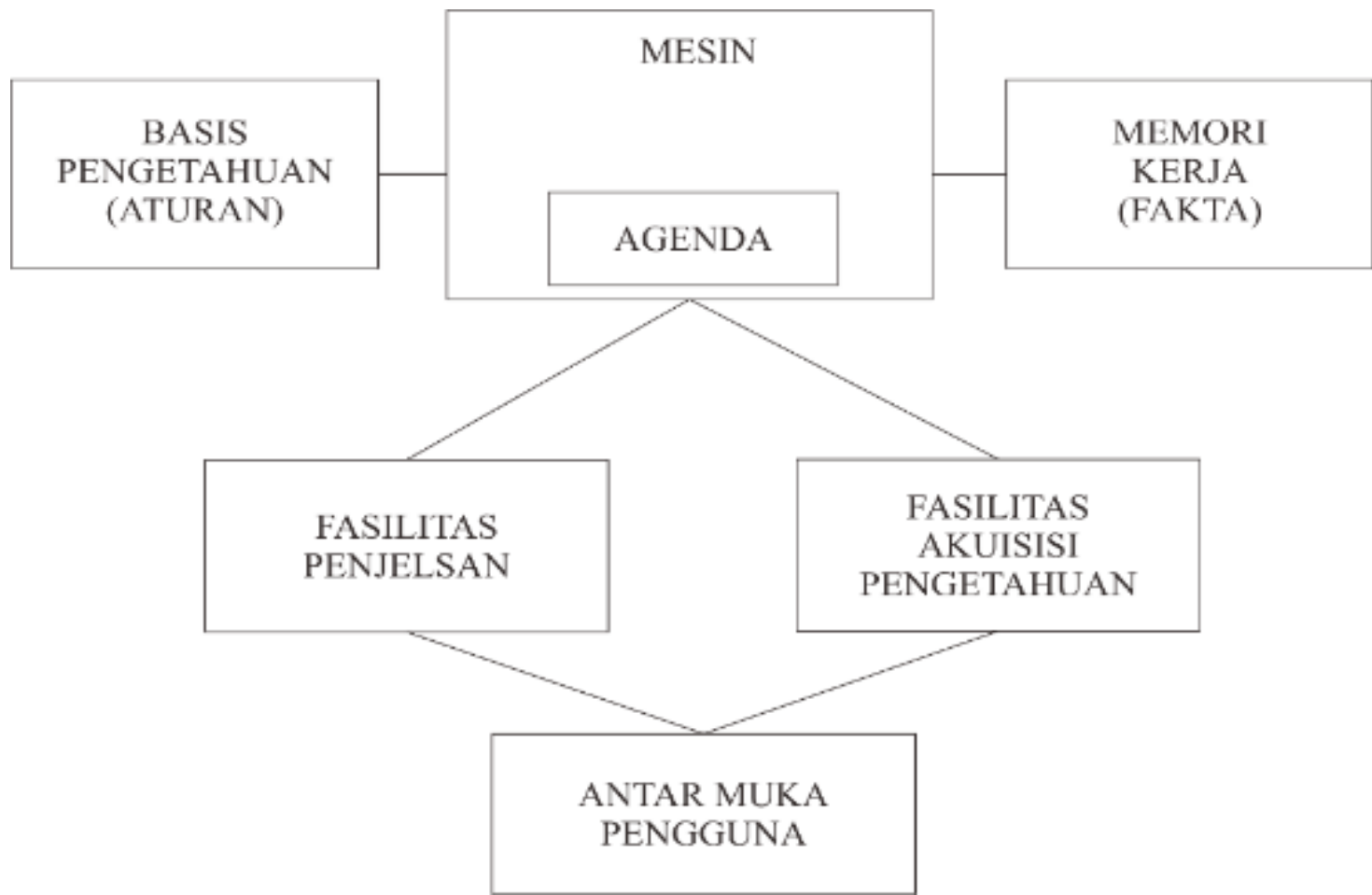

Gambar 1. Arsitektur Sistem Pakar Menurut [10]

\section{Forward Chaining}

Seperti yang terdapat pada penelitian[11],[12],[13],[14],[15] adalah metode yang menggunakan aturan kondisi-aksi. Dalam metode ini menggunakan sejumlah aturan yang akan dijalankan dan selanjutnya aturan dijalankan. Salah ciri dari metode ini adalah dengan cara melakukan penyimpanan pada media storage kerja, kemudian dilakukan pengulangan sampai menemukan sebuah hasil [16]. 


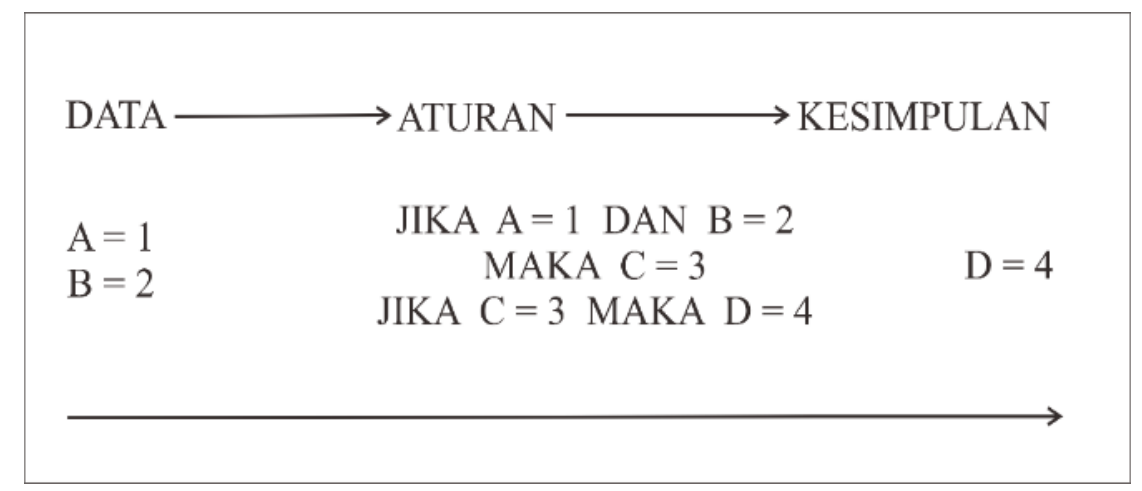

\section{Gambar 2. Forward Chaining}

Metode ini adalah metode yang cocok digunakan dalam menangani masalah pengawasan dan masalah peramalan (prognosis).

\section{Analisis Sistem}

Dalam pengembangan sebuah aplikasi untuk sistem pakar dalam melakukan diagnosa penyakit hipertensi atau diabetes serta cara penanganannya dilakukan dengan beberapa tahapan analisis.

1. Tentukan masalah yang akan dibuatkan solusinya oleh sebuah aplikasi sistem pakar. Sistem yang dibangun merupakan sebuah aplikasi untuk mendiagnosa penyakit hipertensi dan diabetes berbasis web.

2. Mengumpulkan data yang diperlukan untuk membangun sistem, yaitu berupa informasi gejala, penyebab dan cara pengobatannya melalui wawancara dan studi literatur yang digunakan sebagai knowledge base.

3. Mempresentasikan pengetahuan kedalam tabel gejala yang telah dianalisis.

4. Mengusulkan sistem aplikasi yang akan dibuat.

\section{E. Teknik Analisis Forward Chaining}

Teknik forward chaining merupakan teknik dalam penalaran yang diawali dengan sebuah bukti fakta dalam mendapatkan kesimpulan dari sebuah fakta tersebut. Dimana forward chaining adalah suatu strategi inference dari sejumlah fakta yang diketahui. Pencarian dengan cara menjalankan aturan-aturan yang dibuat kemudian premisnya dicocokan dengan fakta dimana diketahui sampai menemukan jenis fakta baru dan menjalankan aturan-aturan sampai berhasil, sehingga tidak menemukan lagoon premisnya yang sesuai dengan fakta terbaru atau fakta yang diperoleh. Berikut ini adalah pelacakan dari metode forward chaining untuk penentuan aplikasi diagnosa penyakit atau kecerdasan buatan untuk diagnosa penyakit hipertensi dan diabetes.

Berikut ini aturan-aturan dalam membangun kepakaran sistem yang dirancang.

1. R1: IF G1 \& G2 \& G6 \& G7 \& G8 \& G9 \& G10 THEN P1.

2. R2: IF G1 \& G3 \& G4 \& G5 \& G11 \& G12 THEN P2.

Fakta yang ada: G1 \& G3 \& G4 \& G5 \& G11 \& G12 benar.

Dalam forward chaining dilakukan dengan cara melakukan pencarian dimulai dari fakta yang diketahui sesuai dengan aturan-aturan dalam mengambil fakta baru yang sudah diketahui dengan penentuan (if) Karena diketahui G1 \& G3 \& G4 \& G5 \& G11 \& G12 bernilai benar, Selanjutnya sistem akan mengambil fakta baru dengan menggunakan aturan yang dimiliki aturan G1 \& G3 \& G4 \& G5 \& G11 \& G12 benar pada sisi jika (if). Dengan menggunakan R2, sistem pakar menentukan P2 adalah benar, jadi hasilnya adalah P2. 


\section{F. Gambar Pohon Keputusan (Decision Tree).}

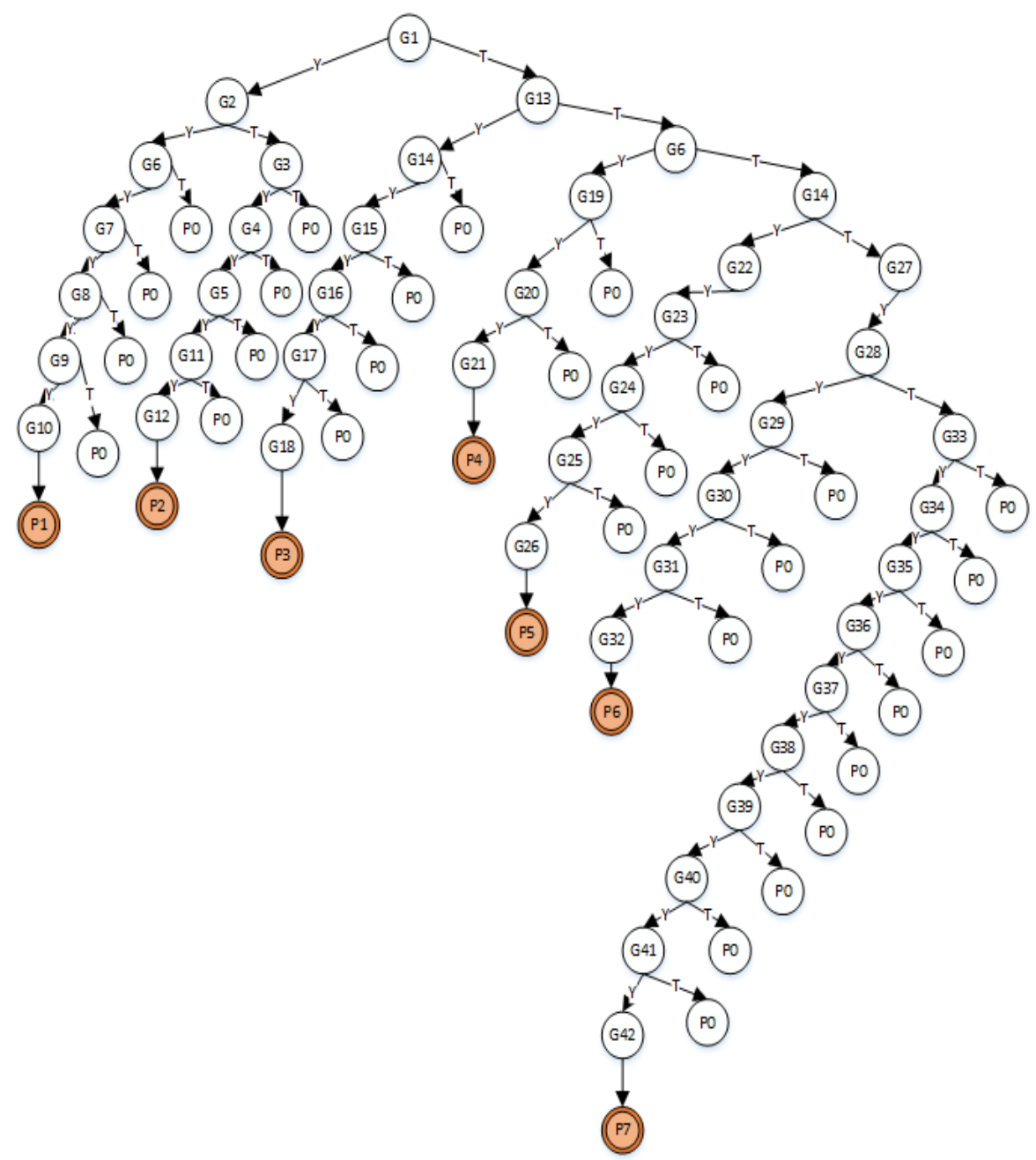

Gambar 3. Pohon Keputusan

\section{G. Teknik Penelitian}

1) Waktu dan Tempat Penelitian

Penelitian dilakukan di Klinik PKO Muhammadiyah Cileungsi yang beralamatkan di Perum PTSC Jl. Anggrek Blok A No. 12 kecamatan Cileungsi kabupaten Bogor. Waktu pelaksanaan penelitian pada tanggal 10 Juni 2018 - 10 Juli 2018.

\section{2) Jenis Data}

Data yang digunakan adalah jenis data sekunder. Dimana data yang didapat dengan cara langsung melalui wawancara dengan pihak dokter untuk mengumpulkan data-data tentang penyakit hipertensi dan diabetes, gejala-gejalanya, penanganan serta pencegahannya. Serta mengumpulkan data dari buku-buku tentang penyakit hipertensi atau diabetes.

\section{3) Teknik Pengumpulan Data}

\section{- Wawancara}

Peneliti mengumpulkan data-data yang dibutuhkan seperti data penyakit diabetes dan hipertensi, data gejala, penyebab dan solusi serta pencegahannya dengan cara tanya jawab langsung kepada dokter yang ditunjuk oleh pihak klinik.

- Studi Pustaka

Pengumpulan data diperoleh dari buku-buku atau penelitian-penelitian dari jurnal yang berhubungan. Dari buku-buku dan jurnal-jurnal tersebut, penulis memperoleh inspirasi dan referensi untuk diterapkan pada penelitian ini. 
JSAI : Journal Scientific and Applied Informatics

Vol. 3, No. 3, November 2020, hal. 86-94

E-ISSN: 2614-3054; P-ISSN: 2614-3062, accredited by Kemenristekdikti, Sinta 5

DOI: 10.36085

\section{HASIL DAN ANALISIS}

Sebagai hasil dari kepakaran sistem untuk diagnosa penyakit tekanan darah tinggi atau hipertensi dan diabetes ini digunakan untuk menentukan apakah seseorang user atau pasien memiliki penyakit hipertensi atau diabetes yang diderita. Metode dalam implementasi dalam menentukan diagnosa penyakit ini menggunakan forward chaining. Hasil yang dikeluarkan sistem berupa persentase penyakit yang terasa oleh pasien. Sehingga nantinya user atau pasien bisa mengetahui tingkat nilai persentase penyakit yang diderita.

3.1 Aplikasi Software dan Hardware yang digunakan

Pada tahap implementasi ini, pengembangan sistem digunakan.

A. Perangkat lunak

Operation System: Linux Ubuntu 18.04 LTS 64 Bit

Bahasa Pemrograman: PHP

Database: MariaDB

Code Editor: Sublime Text

B. Perangkat Keras

Komputer: ASUS X450CA

Processor: Intel Core i3 (1.8 Ghz), RAM 6 GB dan HDD 500 GB.

\subsection{Tampilan Aplikasi}

Sebagai hasil dari perancangan kepakaran sistem diagnosa penyakit untuk tekanan darah tinggi atau hipertensi dan diabetes dengan berbasis pada aplikasi website menggunakan metode diatas dalam pengujiannya saat ini hanya berjalan di localhost saja dan tidak bisa diakses secara online. Berikut ini adalah implementasi tampilan dari aplikasi tersebut.

\subsubsection{Halaman Login}

Halaman login ini merupakan halaman pembuka sebagai interface ketika seorang user ingin masuk ke dalam sistem. pengguna diminta untuk mengisikan nama dan kode akses dan status yang telah terdaftar dalam database sistem, jika pengguna salah memasukan username dan password sistem akan menampilkan pesan nama dan kode akses tidak cocok, jika pengguna benar memasukan nama dan kode akses maka aplikasi akan memasuki area beranda utama.

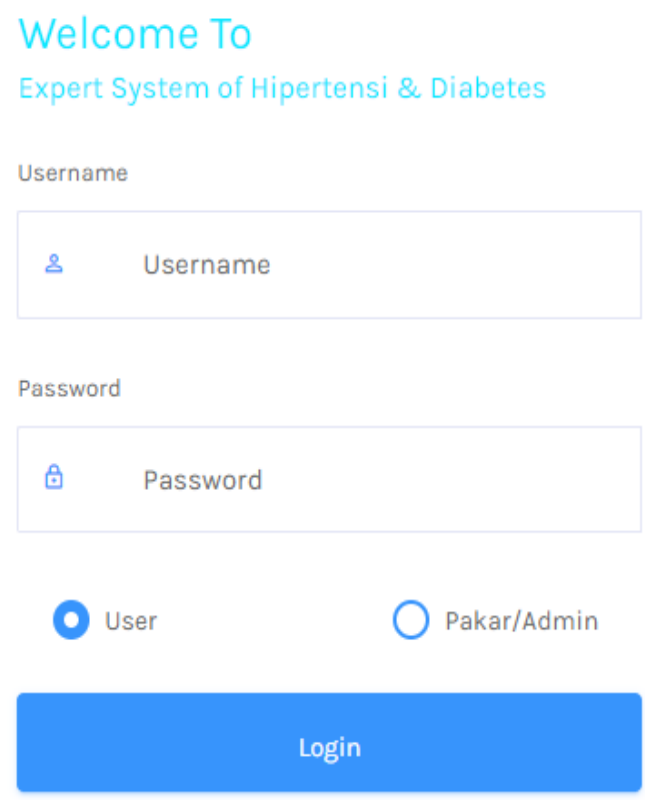

Don't have an account? Create

Gambar 4. Halaman Login 
JSAI : Journal Scientific and Applied Informatics

Vol. 3, No. 3, November 2020, hal. 86-94

E-ISSN: 2614-3054; P-ISSN: 2614-3062, accredited by Kemenristekdikti, Sinta 5

DOI: 10.36085

\subsubsection{Halaman Konsultasi}

Halaman konsultasi ini merupakan halaman dimana user/pasien melakukan konsultasi dengan menjawab pertanyaan yang diajukan sistem.

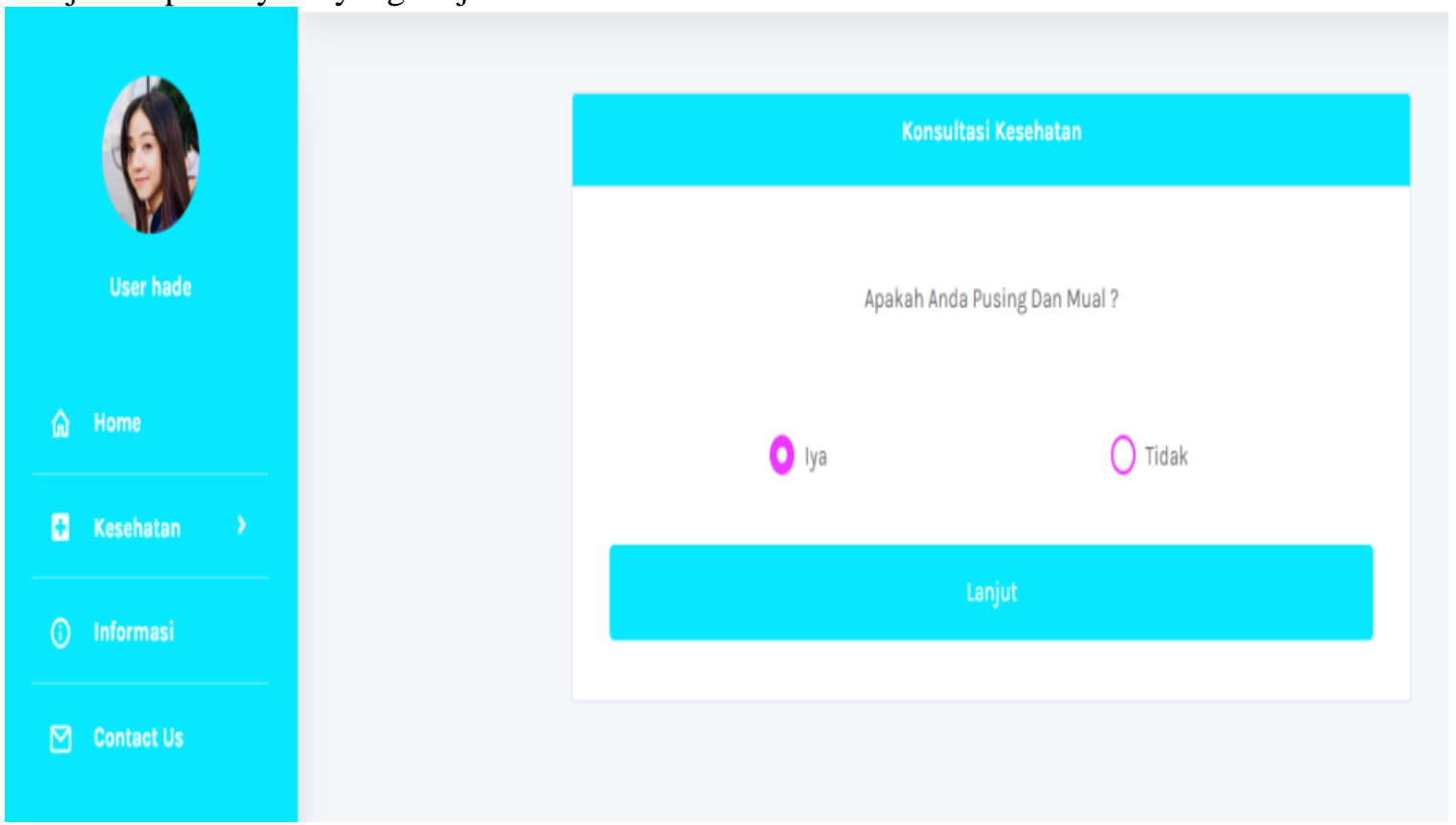

Gambar 5. Halaman Konsultasi

\subsection{Pengujian Sistem}

Untuk mengetahui fungsi dan kualitas dari perangkat lunak yang telah dibangun diperlukan pengujian perangkat lunak. Dalam menguji performance aplikasi yang telah dirancang ini menggunakan metode ISO 9126. Berdasarkan olah data hasil kuesioner penelitian dengan menggunakan sejumlah 20 responden dengan menggunakan model kuesioner SUPR- $Q$ dengan total pertanyaan sebanyak 19 yang dibagi kedalam 6 kategori sesuai dengan ISO 9126. Untuk masingmasing pertanyaan bernilai 5 poin skala likert. Skala likert sendiri memiliki rumus.

$$
\text { Nilai SUPR }-Q=\frac{\text { Jumlah Nilai Diperoleh }}{\text { Jumlah Nilai Maksimal }} \times 100 \%
$$

Nilai Maksimal = Jumlah Item x Nilai Tertinggi x Jumlah Responden

A. Functionality

Faktor functionality terdiri dari 5 pertanyaan yang bertujuan untuk mengetahui fungsionalitas sistem yang telah dibuat ini dari pengguna. Dari 5 pertanyaan dapat dihasilkan nilai sangat baik sebanyak $18 \%$, baik sebanyak $64 \%$, cukup sebanyak $16 \%$ dan kurang sebanyak $2 \%$. Dan untuk skala likertnya mendapatkan nilai sebanyak 78,80 .

B. Reliability

Faktor reliability terdiri dari 3 pertanyaan yang bertujuan untuk mengetahui kehandalan sistem. Dari 3 pertanyaan dapat dihasilkan nilai sangat baik sebanyak $8 \%$, baik sebanyak $80 \%$, dan cukup sebanyak $12 \%$. Dan untuk skala likertnya mendapatkan nilai sebanyak 77,66.

C. Usability

Faktor usability terdiri dari 4 pertanyaan yang bertujuan untuk mengetahui kemampuan sistem yang telah dibuat. Dari 4 pertanyaan dapat dihasilkan nilai sangat baik sebanyak 13\%, baik sebanyak 58\%, dan cukup sebanyak 29\%. Dan untuk skala likertnya mendapatkan nilai sebanyak 76,25 .

D. Efficiency

Faktor efficiency terdiri dari 2 pertanyaan yang bertujuan untuk mengetahui kinerja sistem yang telah dibuat. Dari 2 pertanyaan dapat dihasilkan nilai sangat baik sebanyak 10\%, baik sebanyak $58 \%$ dan cukup sebanyak $32 \%$.

E. Maintainability 
Faktor maintainability terdiri dari 2 pertanyaan yang bertujuan untuk mengetahui kemampuan sistem untuk beradaptasi dengan lingkungan perangkat yang berbeda. Dari 2 pertanyaan dapat dihasilkan nilai sangat baik sebanyak $16 \%$, baik sebanyak 51\%, dan cukup sebanyak 33\%. Dan untuk nilai skala likertnya mendapatkan nilai sebanyak 76,50.

\section{F. Portability}

Faktor portability terdiri dari 3 pertanyaan yang bertujuan untuk mengetahui kemampuan sistem untuk ditransfer. Dari 3 pertanyaan tersebut dapat dihasilkan nilai sangat baik sebanyak 5\%, baik sebanyak $67 \%$, dan cukup sebanyak $28 \%$. Dan untuk skala likertnya mendapatkan nilai sebanyak 75.33 .

\section{KESIMPULAN}

Berdasarkan hasil penelitian dan pengembangan aplikasi sistem pakar dalam mendiagnosa penyakit kelebihan kadar gula dalam tubuh atau diabetes dan tekanan darah yang tinggi atau hipertensi menggunakan metode forward chaining maka dapat diambil suatu kesimpulan sebagai berikut: (1) Bahwa aplikasi sistem pakar untuk diagnosa penyakit hipertensi dan diabetes dengan menggunakan metode forward chaining di Klinik PKO Muhammadiyah Cileungsi membantu mendiagnosa penyakit hipertensi atau diabetes sehingga lebih memudahkan bagi para pasien atau pengguna. (2) Aplikasi sistem pakar ini memiliki basis pengetahuan yang dinamis, bila terdapat penyakit dan gejala-gejala baru dapat ditambahkan tanpa mengubah kode program.(3) Pengujian sistem menggunakan ISO 9126, aplikasi pihak ketiga, dan juga 20 responden dari lingkungan yang berbeda, dari hasil pengujian tersebut aplikasi sistem pakar diagnosa penyakit hipertensi atau diabetes menggunakan metode forward chaining di Klinik PKO Muhammadiyah Cileungsi masuk kedalam kategori "Baik" sehingga layak untuk digunakan sebagai alat untuk menentukan diagnosa penyakit hipertensi atau diabetes di Klinik PKO Muhammadiyah Cileungsi.

\section{UCAPAN TERIMA KASIH}

Terima kasih kasih saya sampaikan kepada Ketua STTMC dan LPPMPK yang support dalam penulisan artikel ini.

\section{REFERENSI}

[1] B. H. Hayadi, Sistem Pakar. Deepublish, 2016.

[2] Setiabudi, "Referensi Kesehatan Diabetes Melitus, 2008. [Online]," Available http//creasoft.wordpress.com/2008/04/15/diabetesmelitus/..[Diakses 12 January 2019], 2019.

[3] R. K. RI, "Hipertensi, The Silent Killer, 12 May 2015 [Online].," Available http//pusdatin.kemkes.go.id. [Diakses 12 Januari 2019].

[4] M. Arhami, Konsep Dasar Sistem Pakar. Yogyakarta: Andi offset, 2005.

[5] j. Martin dan S. Oxman, Building Expert Systems: A Tutorial. New Jersey: Prentice Hall, 1988.

[6] L. Septiana, S. Nusa, M. Jakarta, J. Kramat, R. N. 18, and J. Pusat, "Perancangan Sistem Pakar Diagnosa Penyakit Ispa Dengan Metode Certainty Factor Berbasis Android," J. TECHNO Nusa Mandiri, vol. XIII, no. 2, p. 89, 2016.

[7] S. Halim and S. Hansun, "Penerapan Metode Certainty Factor dalam Sistem Pakar Pendeteksi Resiko Osteoporosis dan Osteoarthritis," J. Ultim. Comput., vol. 7, no. 2, pp. 59-69, 2016.

[8] S. A. Putri and E. P. Saputra, "Perancangan Aplikasi Sistem Pakar Diagnosa Awal Kanker Reproduksi Wanita Dengan Metode Certainty Factor," J. Media Inform. Budidarma, vol. 2, no. 3, pp. 63-68, 2018.

[9] A. A. Pramesti, R. Arifudin, and E. Sugiharti, "Expert System for Determination of Type Lenses Glasses Using Forward Chaining Method," Sci. J. Informatics, vol. 3, no. 2, pp. 177-188, 2016.

[10] J. G. dan G. Riley, Expert System Principles and Programming. Boston: PWS Publishing Company, 1994.

[11] F. Masya, H. Prastiawan, and S. Mubaroq, "Application Design to Diagnosis of Bone Fracture ( Traditional ) using Forward Chaining Methods," Int. Res. J. Comput. Sci., vol. 3, no. 09, pp. 23-30, 2016. 
JSAI : Journal Scientific and Applied Informatics

Vol. 3, No. 3, November 2020, hal. 86-94

E-ISSN: 2614-3054; P-ISSN: 2614-3062, accredited by Kemenristekdikti, Sinta 5

DOI: 10.36085

[12] W. Verina, "Penerapan Metode Forward Chaining untuk Mendeteksi Penyakit THT," J. Tek. Inform. Dan Sist. Inf., vol. 1, no. 2, pp. 123-138, 2015.

[13] I. Akil, "Analisa Efektifitas Metode Forward Chaining Dan,” J. Pilar Nusa Mandiri, vol. 13, no. 1, pp. 35-42, 2017.

[14] G. A. D. Sugiharni and D. G. H. Divayana, "Pemanfaatan Metode Forward Chaining Dalam Pengembangan Sistem Pakar Pendiagnosa Kerusakan Televisi Berwarna," J. Nas. Pendidik. Tek. Inform., vol. 6, no. 1, p. 20, 2017.

[15] A. A. Perbawawati, E. Sugiharti, and M. A. Muslim, "Bayes Theorem and Forward Chaining Method On Expert System for Determine Hypercholesterolemia Drugs," Sci. J. Informatics, vol. 6, no. 1, pp. $116-124,2019$.

[16] W. B, "The All Dictionary 1998. [Online]," Available http//www.csc.unsw.edu.au/ bilKv/aidict.html. [Diakses 02 Maret 2019]. 